This volume is a product of the staff of the International Bank for Reconstruction and Development/The World Bank. The World Bank does not guarantee the accuracy of the data included in this work. The findings, interpretations, and conclusions expressed in this paper do not necessarily reflect the views of the Executive Directors of the World Bank or the governments they represent.

The material in this publication is copyrighted.

\title{
FinANCIAL SECTOR AsSessment PROgRAM - DEVELOPMENT MODULE EL SALVADOR
}

\section{NON-BANK SAVINGS AND CREDIT INSTITUTIONS TECHNICAL NOTE} NOVEMBER 2016

This Technical Note was prepared in the context of a World Bank Financial Sector Assessment Program mission in the Republic of El Salvador in March 2016 led by John Pollner and overseen by Finance and Markets Global Practice, World Bank. The document contains technical analysis and detailed information underpinning the FSAP assessment's findings and recommendations. Further information on the FSAP program can be found at www.worldbank.org/fsap.

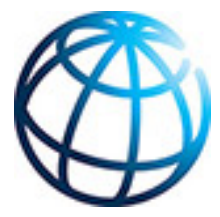

THE WORLD BANK

FinANCE AND MARKETS GLOBAL PRACTICE

LATIN AMERICA AND THE CARIBBEAN REGION 


\section{CONTENTS}

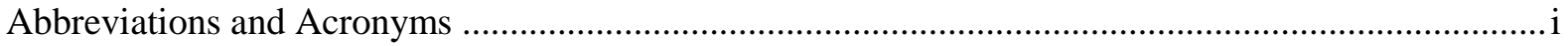

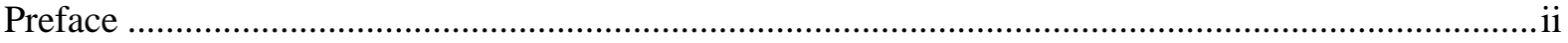

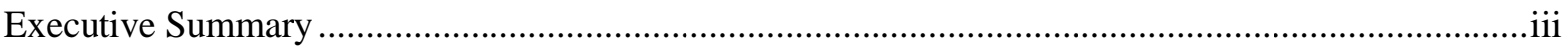

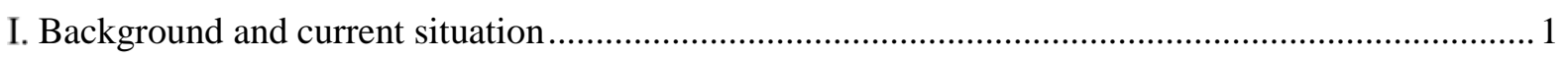

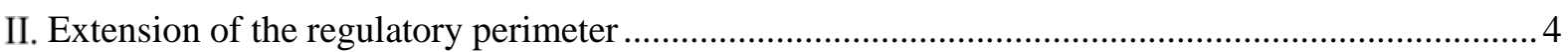

III. Select Latin American experiences on supervision of NBSCI ...................................................... 6

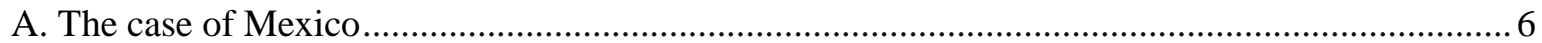

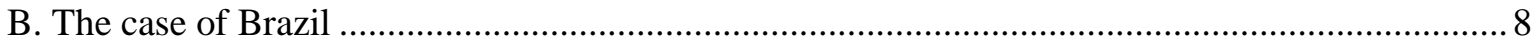

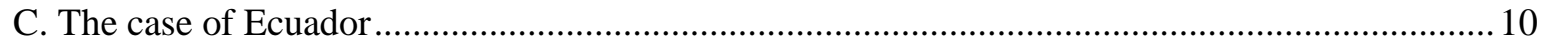

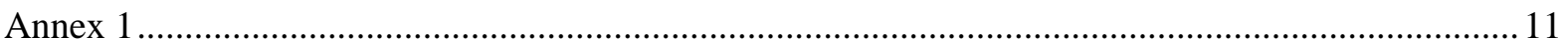




\section{ABbreviations AND ACRONYMS}

\section{ABANSA}

Bandesal

BCR

BL

CAR

CBB

CBL

CNBV

FEDECACES

FEDECRECE:

FEDECREDITO

FSAP

FSG

IGD

IFI

INSAFOCOOP

NBSCI

SAC

SEPS

SCAP

SOFIPO

SOFOM

SSF
Banking Association

Banco de Desarrollo de El Salvador

Central Bank of El Salvador (Banco Central de Reserva)

Bank Law

Capital Adequacy Ratio

Central Bank of Brazil

Cooperative Banking Law

National Banking and Securities Commission (Comisión Nacional Bancaria de Valores-Mexico)

Salvadoran Federation of Associations of Cooperatives and Savings and Loans

Federación de Asociaciones Cooperativas de Ahorro, Crédito y Servicios Múltiples Afines de El salvador,

Federation of Credit Unions and Worker's Banks

Financial Sector Assessment Program

Salvadoran Guarantee Fund (Fondo Salvadoreño de Garantías)

Deposit Insurance Fund (Instituto de Garantía de Depósitos)

International Financial Institutions

Salvadoran Institute of Cooperative Development

Non-Bank Savings and Credit Institutions

Savings and Credit Institution (Sociedades de Ahorro y Credito)

Superintendency of Popular and Solidarity Economy (Superintendencia de Economía Popular y Solidaria-Ecuador-)

Saving and Loan Cooperative (Sociedad Cooperativa de Ahorro y Préstamos -México-)

Popular Financial Company (Sociedad Financiera Popular-México)

Multi-Purpose Financial Companies (Sociedad Financiera de Objeto Múltiple -México)

Financial System Superintendence (Superintendencia del Sistema Financiero, El Salvador) 


\section{Preface}

A World Bank mission visited San Salvador from March 6 to 16, 2016 to update the developmental aspects of the Financial Sector Assessment Program (FSAP) conducted in 2010. ${ }^{1}$ As agreed with the authorities, this FSAP Development Module focused on (i) financial systems issues, including competition and efficiency; (ii) financial inclusion and non-bank financial institution issues, (iii) public sector banks, (iv) financial system infrastructure, including payments, remittances transfers, and credit information systems; (v) capital market and private pensions development issues; and (iv) insurance.

With the main aim to review the regulatory and supervisory topics of Non-Bank Savings and Credit Institutions (NBSCI) as well as some of the main characteristics of the NBSCI sector, there were meetings with the main stakeholders, including the Central Bank of El Salvador (Banco Central de la Reserva - BCR), the Financial Sector Superintendence (Superintendencia del Sistema Financiero, SSF), private commercial banks, cooperative banks, savings and credit companies, and microfinance institutions, development banks, public financial sector institutions. Finally, there were meetings with two cooperative federations (FEDECACES and FEDECREDITO) and with the Salvadorian banking association (ABANSA).

Section V of the Technical Note ${ }^{2}$ describes the background and current situation of the sector of NBSCI in El Salvador, including its legal and regulatory framework, and its main characteristics. Section VI discusses challenges related to the potential expansion of the regulatory perimeter in El Salvador. Section VII includes a description of some auxiliary supervisory experience of NBSCI in Latin America that, although are for countries with a more developed NBSCI sector and its regulatory/supervisory framework, could provide useful insights for El Salvador.

\footnotetext{
${ }^{1}$ The team comprised John Pollner (Mission Chief), Rekha Reddy (Deputy Mission Chief), Maria Teresa Chimienti, Denise Dias, Tamuna Loladze, Fredesvinda Montes, Mateo Clavijo Munoz (all World Bank staff); José Rutman (Former Regulation General Deputy Manager, Central Bank of Argentina), and Monica Caceres (Former Deputy Superintendent, Insurance, Chile).

2 This note was prepared by José Rutman with input from John Pollner and Rekha Reddy.
} 


\section{EXECUTIVE SUMMARY}

The Salvadoran legal framework considers varied NBSCI, establishing the factors that trigger their inclusion within the regulatory perimeter. There is a range of NBSCI, some of which are under the regulation and supervision of the SSF.

The funding of regulated and non-regulated NBSCI include deposits, bank lending, loans from abroad (including donors and International Financial Institutions -IFIs) and loans/guarantees from Bandesal (Banco de Desarrollo de El Salvador).

The regulatory framework for regulated NBSCI has no substantial differences with the requirements established to banks. However, the legal framework for the regularization and resolution process of cooperatives is unclear and presents uncertainties, which could limit its effective implementation. The savings and credit institutions (sociedades de ahorro y crédito, SACs) are small specialized institutions that can perform similar operations to banks.

There are two active federation bodies (of which only one is supervised by SSF) that provide different types of services to NBSCI, including a self-regulatory and supervisory framework.

INSAFOCOOP, the Salvadoran Institute of Cooperative Development in charge of registering, supervising and promoting cooperatives, does not exercise prudential supervision on cooperatives. There is no public information available (neither to the general public nor to the SSF/BCR) of the financial statements (and other financial information) of the nonregulated NBSCI, which limits SSF's exercise of supervision, the analysis of the performance of the market and the effectiveness of market discipline

There are preliminary draft laws to extend the regulatory perimeter of NBSCI, including the use of auxiliary supervision by the SSF. The proposal includes an amendment on the CBL, expanding the concept and reducing the threshold for being a cooperative bank regulated and supervised by the SSF. According to preliminary information provided by INSAFOCOOP, around 23 new cooperatives (with $\$ 716$ million of assets) will fall under the new regulatory perimeter of SSF.

The auxiliary supervisory scheme based on specialized external auditors and federations requires proper design and control by the SSF to avoid potential conflicts of interest. The SSF should establish the minimum standard with which the auxiliary supervision should comply, and supervise its effective implementation both by the federation and by the contracted external auditor.

The appropriate incentives should be considered to ensure the compliance of NBSCI of the applicable prudential regulations within the maximum deadline legally established. The deposit insurance and resolution framework applicable for cooperative banks and for the new type of financial cooperatives should be clarified and reinforced. The legal framework should consider the possibility for the SSF and the BCR to have access to the financial statements of the cooperatives that are outside the regulatory perimeter.

The SSF should enhance and reinforce the training and number of supervisors to be prepared for its supervision of the new entities. INSAFOCOOP should be strengthened to be able to perform certain prudential supervision of cooperatives that are outside the regulatory perimeter of the SSF. 
Some Latin-American countries have adopted -with different approaches- auxiliary supervision in their supervisory scheme of NBSCI. The strengths and weaknesses of the approaches of Mexico, Brazil and Ecuador are discussed in this technical note. Although these countries might have a more developed NBSCI sector and a more advanced legal and regulatory framework, its experiences could be useful to be taken into account for the case of El Salvador.

Table of Recommendations

\begin{tabular}{|c|c|c|}
\hline & Timeframe & Priority \\
\hline $\begin{array}{l}\text { The BCR and SSF should develop a consensus version of a draft law for } \\
\text { the extension of the regulatory perimeter to cooperatives. }\end{array}$ & ST & High \\
\hline $\begin{array}{l}\text { The draft law should include: } \\
\text { - } \quad \text { Incentives for the prompt compliance with the regularization plan } \\
\text { applicable for the institutions entering into regulatory perimeter } \\
\text { - } \quad \text { Mechanisms to mitigate potential conflict of interest arising from } \\
\text { auxiliary supervision } \\
\text { - } \\
\text { Access to financial information from unregulated financial } \\
\text { institutions. }\end{array}$ & ST & High \\
\hline $\begin{array}{l}\text { Clarify and reinforce the deposit insurance and resolution framework } \\
\text { applicable for cooperative banks and for the new type of financial } \\
\text { cooperatives. }\end{array}$ & ST & High \\
\hline $\begin{array}{l}\text { The SSF should reinforce its training and prepare staff for the supervision } \\
\text { of additional NBSCI under its responsibility. }\end{array}$ & $\mathrm{ST}$ & High \\
\hline $\begin{array}{l}\text { Strengthen the capacity of INSAFOCOOP to provide prudential } \\
\text { supervision of financial cooperatives outside the regulatory perimeter of } \\
\text { the SSF. }\end{array}$ & MT & Medium \\
\hline
\end{tabular}




\section{BACKGROUND AND CURRENT SITUATION}

1. The legal framework contemplates different type of regulated NBSCI, establishing for the cooperatives the factors that trigger the inclusion of them in the regulatory perimeter. Article 114 of the National Constitution establishes, without distinguishing if they operate with their members or not, that the State shall protect and promote the cooperative associations, facilitating their organization, expansion and financing. In February 2000 the law on "Non-Bank Financial Intermediaries" was approved; afterwards (September 2008) this law was reformed and renamed as "Law on Cooperative Banks and Saving and Credit Companies (CBL)”, being the current applicable legal framework for NBSCI. The aforementioned law establishes that any cooperative that receives deposits not only from its member but also from the general public and/or whose total deposits plus contributions surpass USD92.8 million will fall within that law and the regulatory/supervisory perimeter of the SSF. Other institutions covered by this law are: the federation of cooperatives that will perform financial intermediation with their affiliates and the SAC.

2. There is a range of NBSCI, some of which are under the regulation and supervision of the SSF. There are 11 regulated institutions under the CBL, including 4 SAC, 2 saving and loan cooperatives, 4 Workers' Banks (banco de los trabajadores) and one Federation (FEDECREDITO). Their total assets (without counting the federation) is $\$ 0,9 \mathrm{bn}$, which represents around one-third of the estimated total assets of the NBSCI sector. The unregulated institutions include two Saving and Loan Coops Federation (FEDECACES and FEDECRECE), 58 Credit Unions and Workers' Banks, and an estimated 448 saving and loans coops. The unregulated institutions have an estimated total asset of $\$ 1.9 \mathrm{bn}^{3}$, two-thirds of the total assets estimated for the sector (see Figure 1).

Figure 1: Non-Bank Savings and Credit Institutions (NBSCI) As of Dec 2015

\begin{tabular}{|c|c|c|c|}
\hline & $\begin{array}{c}\text { \# of } \\
\text { institutions }\end{array}$ & $\begin{array}{c}\text { Assets } \\
\text { (bn \$) }\end{array}$ & $\begin{array}{c}\text { Regulated } \\
\text { by SSF }\end{array}$ \\
\hline Saving and Loan Companies & 4 & 0,2 & Yes \\
\hline Cooperative Banks* & 7 & 0,7 & Yes \\
\hline Saving and Loans Coops & 2 & 0,4 & Yes \\
\hline "Banco de los Trabajadores" (BT) & 4 & 0,3 & Yes \\
\hline Federation (Credit Union \& BT) FEDECREDITO & 1 & & Yes \\
\hline Sub Total of Regulated & 11 & 0,9 & \\
\hline FEDECACES (Saving and Loans Coop Federation) & 1 & & No \\
\hline FEDECRECE (Saving and Loans Coop Federation) & 1 & & No \\
\hline Credit Unions and BT (associated to Fedecredito) & 51 & 1,1 & No \\
\hline Saving and Loans Coops & 448 & 0,8 & No \\
\hline Sub Total estimated of Unregulated * & 501 & 1,9 & \\
\hline Estimated Total of NBFI & 512 & 2,8 & \\
\hline
\end{tabular}

The information on unregulated NBCI is an estimation based on partial information available. Source: FSAP elaboration with data from SSF, FEDECREDITO and INSAFOCOOP.

\footnotetext{
${ }^{3}$ There is no official published information about the total number and assets of the unregulated NBSCI. The estimations included came from partial information available from FEDECREDITO and INSAFOCOOP.
} 
3. The funding of regulated and non-regulated NBSCI include deposits, bank lending, loans from abroad and loans/guarantees from Bandesal (Banco de Desarrollo de El

Salvador). Loans from abroad include donors, international banks and International Financial Institutions (IFIs), while Bandesal provides to the NBSCI both second-tier funding as well as partial guarantees through the Salvadoran Guarantee Fund (FSG).

4. The regulatory framework for regulated NBFI has no substantial differences with the requirements established to banks. Some differences exist related with a lower nominal minimum capital required (although the required capital over risk weight assets $-12.0 \%$ - is the same for both type of institutions) and the possibility of constituting $50 \%$ of the liquidity requirements in banks (instead of having to deposit them at the Central Bank of El Salvador $\left.\mathrm{BCR}^{4}\right)$.

5. The legal framework for the regularization and resolution process of cooperatives is unclear and presents uncertainties, which could limit their effective implementation. Some examples are: (a) the CBL has specific sections and articles establishing aspects related to the regularization, intervention and dissolution of cooperatives, as well as the existence and functioning of a Stabilization Fund; the same law (article 106) establishes that it applies Titles IV and VI of the Banking Law, which present differences with the aforementioned sections and articles; (b) the same article 106, establishes that the Deposit Insurance Agency (Instituto de Garantía de los Depósitos -IGD-) must have separate (from the banks) administration and accounts for the cooperative banks; then, it is unclear if the IGD could use the resources accounted at the Bank and SAC IGD's Fund account in case the Cooperative Banks IGD's Fund does not have enough resources to pay the deposit insurance of a failed cooperative bank (which might be the case for almost any of the cooperative banks; see Figure 2); and (c) the SSF has not granted the cooperative banks an "official” license; so they might have difficulties (legal challenges) in revoking it.

\section{Figure 2: Insured Deposits of Cooperative Banks and Resources of the IGD}

\begin{tabular}{|c|c|c|c|}
\hline As of December 2015 & $\begin{array}{c}\text { Insured } \\
\text { deposits } \\
(\text { mill \$) }\end{array}$ & $\begin{array}{c}\text { \% over Coop } \\
\text { Banks IGD's } \\
\text { Fund }\end{array}$ & $\begin{array}{c}\% \text { over } \\
\text { Banks and } \\
\text { SAC IGD's } \\
\text { Fund } \\
\end{array}$ \\
\hline Coop Bank 1 & 2,62 & $86 \%$ & $2 \%$ \\
\hline Coop Bank 2 & 5,81 & $190 \%$ & $4 \%$ \\
\hline Coop Bank 3 & 8,66 & $284 \%$ & $6 \%$ \\
\hline Coop Bank 4 & 9,18 & $301 \%$ & $7 \%$ \\
\hline Coop Bank 5 & 39,76 & $1302 \%$ & $29 \%$ \\
\hline Coop Bank 6 & 41,07 & $1345 \%$ & $30 \%$ \\
\hline \multicolumn{4}{|l|}{ Funds at the IGD (mill \$) } \\
\hline Banks and SAC IGD's Fund & 134,82 & & \\
\hline Cooperative Banks IGD's Fund & 3,05 & $100 \%$ & \\
\hline Total & 137,88 & & $100 \%$ \\
\hline
\end{tabular}

\section{The SACs are small specialized institutions that can perform similar operations to}

banks. The 4 authorized institutions have focused in different segments of the market (microfinance, consumption loans, SMEs, etc.). Some of them have started to provide checking accounts to their clients. The minimum nominal capital required is lower than banks, which

\footnotetext{
${ }^{4}$ For operating with checking account, the cooperatives have to deposit all the liquidity requirements at theircorresponding account at the BCR (on September 2016, BCR approved a change in the regulation where the $100 \%$ liquidity reserve requirement to the Cooperative Banks that implement current account was replaced by a $50 \%$ requirement established in the "Normas para el Cálculo y Utilización de la Reserva de Liquidez sobre Depósitos y otras Obligaciones" -NPB3-06)-.
} 
reduces barriers to entry and facilitates the potential participation of local investors in the Salvadoran financial market.

7. There are two active federation bodies (of which only one is supervised by SSF) that provide different types of services to NBSCI, including a self-regulatory and supervisory framework. FEDECREDITO, which is regulated by the SSF and has 55 associated entities including credit unions and workers' banks - banco de los trabajadores (only 4 of these institutions, all workers' banks, are regulated and supervised by SSF), operates as a second-tier entity, with the following activities and tasks: standardization of deposit products and credit, management of corporate business (debit / credit, remittances), administration of electronic channels and common computer systems; organization of compensation between members and provision of training and advisory services, among others. In addition, it has developed prudential regulations based on SSF/BCR's regulation, and performs certain on-site and off-site supervision on the compliance of this regulation by its member institutions. The other federation body, FEDECACES, is not regulated by the SSF and has 32 members (all of them saving and loan cooperatives) with similar activities as FEDECREDITO albeit with a narrower scope.

8. The institution in charge of registering, supervising and promoting cooperatives (INSAFOCOOP) does not exercise prudential supervision of cooperatives. INSAFOCOOP has 1,078 cooperatives registered, of which 447 are financial cooperatives and, among them, only $2^{5}$ are regulated and supervised by the SSF. INSAFOCOOP has limited staff (17 auditors for the supervision and 18 people for promotion of all the institutions registered) and their tasks are confined to registration, receiving accounting information, addressing legal issues and providing advice. Although they intend to strengthen the prudential regulation and supervision of the financial cooperatives, they do not have the resources and capacity to do it.

9. There is no public information available (neither to the general public nor to the SSF/BCR) of the financial statements (and other financial information) of the nonregulated NBSCI, which limits SSF's exercise of supervision, the analysis of the performance of the market and the effectiveness of market discipline. Both Federations and INSAFOCOOP believe that the information of these institutions is for exclusive interest of their members and should not be publicly disclosed and shared with the SSF. Hence, the SSF cannot detect when a NBSCI exceeds the threshold to be regulated and has not presented that situation to the SSF. The SSF cannot detect how many NBSCI are close to the threshold, nor can it keep track of developments of the market where NBSCI operate. Additionally, the lack of standardized and easily accessible information of cooperatives reduces the (already low) capacity of the cooperative's current or potential members to compare the performance of the different cooperatives.

\footnotetext{
${ }^{5}$ Comédica and Vicentina.
} 


\section{EXTENSION OF THE REGULATORY PERIMETER}

10. There are preliminary draft laws to extend the regulatory perimeter of NBSCI, including the use of auxiliary supervision by the SSF. Currently, there are 2 draft laws (one prepared by the SSF and the other by the $\mathrm{BCR}^{6}$ ) with some commonalities between both of them. Both initiatives propose that cooperatives that have between $\$ 10$ and $\$ 30$ million of deposits plus contributions and/or assets will fall into a new category of institution to be regulated and supervised by the SSF. For this purpose, a specific legal framework, similar to that for cooperative banks, is created. The draft includes a role for auxiliary supervision of these institutions through the federations of those institutions and through specialized external auditors hired by the SSF. In the case of institutions not affiliated to a federation, the supervision will be performed only through the specialized external auditors and the SSF (with no involvement of a federation). Annex 1 describes the main differences between them.

11. The proposal includes an amendment on the CBL, expanding the concept and reducing the threshold for being a cooperative bank regulated and supervised by the SSF. Currently, any cooperative having deposits plus contributions over $\$ 92.8$ million is regulated and supervised by the SSF under the CBL. Both (the SSF and the BCR's) draft laws propose to expand the concept to be measured including deposits plus contributions (concept currently used) or assets (new concept incorporated), and to reduce the threshold to \$30 million (less than one-third the current level) ${ }^{7}$.

12. According to preliminary information provided by INSAFOCOOP, around 23 new cooperatives (with $\mathbf{\$ 1 1 6}$ million of assets) will fall under the new regulatory perimeter of SSF. The $\$ 30$ million floor is surpassed by 10 cooperatives (including FEDECACES) that are not currently regulated by SSF (with total assets of $\$ 477$ million). Additionally, 13 cooperatives with assets between $\$ 10$ and $\$ 30$ million will fall under the new type of cooperative (with total assets of \$239 million). Finally, 10 cooperatives with assets between 7 and 10 million will be relatively close to entering into the regulatory perimeter in the short and medium term. These figures likely underestimate the total number of institutions that would enter into the regulatory perimeter, since it does not include the credit unions (whose information has not been available).

13. The auxiliary supervisory scheme based on specialized external auditors and federations requires proper design and control by the SSF to avoid potential conflicts of interest $^{8}$. Despite using auxiliary supervision, the responsibility for the oversight of cooperatives remains at the SSF. The federations provide technical services and support for which they charge the NBSCI, and could be influenced and conditioned to act when regulatory breaches or weaknesses are detected in one of their associated entities. The alternative of using auxiliary external auditors hired by the SSF (included in one of the draft laws) to verify compliance and evaluation of internal policies and risk management could be an alternative to mitigate conflicts of interests.

14. The SSF should establish the minimum standard with which the auxiliary supervision should comply, and supervise its effective implementation both by the federation and by the hired external auditor. The SSF should have and should perform, at any time, the possibility to exercise direct supervision, and be the only body with the power to

\footnotetext{
${ }^{6}$ Afterwards (as noted by the Salvadorian authorities on their comments to the TN), the BCR and SSF agreed on one consensual draft law (reforming the CBL instead of having a separate new lew).

7 The new draft law reduces the threshold to $\$ 10$ million.

${ }^{8}$ The new draft law considers only direct supervision of the SSF (does not contemplate any delegated and/or auxiliary supervision)
} 
impose sanctions and penalties. The fees charged to the NBSCI for being supervised (either directly or using auxiliary supervision) should be included in the law (e.g. as a percentage of the assets of the supervised institution) and channeled through the SSF to be distributed to the external auditor, the federation and the SSF.

\section{The appropriate incentives should be considered to ensure the compliance of} NBSCI of the applicable prudential regulations within the maximum deadline legally established. The SSF should be granted explicit authority that, if the regularization plan is not completed within the maximum period established by law (2 years), they may apply sanctions, including immediate suspension of the entity, or its dissolution ${ }^{9}$. A complementary incentive could be the incorporation of the cooperative to the deposit insurance mechanism only when it complies with the regularization plan and when the SSF has granted an authorization to continue performing its operations. The above recommendations should apply to both the new cooperative banks (with deposits plus contributions or assets above $\$ 30$ million) and the other cooperative entities entering into the regulatory perimeter (between with deposits plus contributions or assets between $\$ 10$ and \$30 million).

16. The deposit insurance and resolution framework applicable for cooperative banks and for the new type of financial cooperatives should be clarified and reinforced ${ }^{\mathbf{1}}$. These issues are already relevant for the current number of institutions involved; considering the entrance of new institutions, it became urgent to be solved as soon as possible.

\section{The legal framework should consider the possibility for the SSF and the BCR to} have access to the financial statements of the cooperatives that are outside the regulatory perimeter. An alternative (included in one of the draft law) could be to require cooperatives to report directly to the SSF. Although this might solve the problem of lack of access to the data, it could face sectorial resistance (e.g. to have direct requirements from SSF). Another alternative could be to include in the law that any federation and INSAFOCOOP are obligated to report such information to the SSF, while the (few) institutions that are neither federated nor registered at INSAFOCOOP should report directly to the SSF.

18. The SSF should enhance and reinforce the training and number of supervisors to be prepared for its supervision of the new entities. If the regulatory perimeter is expanded, the number of NBSCI that the SSF would have in charge could be multiplied by 3 or 4 (there is no exact figures available) from the current number. When added to the distinctive characteristics of these institutions (small size, cooperative form, etc.), this presents a significant challenge for the SSF. The use of auxiliary supervision mechanisms will only marginally reduce the initial effort, as training and supervision of those who will carry out this auxiliary supervision by the SSF will be time consuming as well as essential. While the new institutions have no systemic impact, the consequences of an inadequate supervision would be relevant for the clients / members of such entities (particularly vulnerable populations), the general view of the financial sector and the reputation of the SSF as supervisor.

\footnotetext{
${ }^{9}$ The new draft law establishes certain incentives (e.g. the coops that do not comply with the regularization plan will not be member of IGD and will not have deposit insurance)

${ }^{10}$ The new draft law clarifies this point. Under this draft, Title II of the LBCSAC (regularization, special supervision, intervention, dissolution and liquidation) is abolished, making clear that it has to be applied Title IV of the Banking Law. Additionally, article 106 of the LBCSAC is reformed, providing clarity on the usage of the deposit insurance fund managed by the Deposit Insurance Agency (IGD); the approach is that the capital of IGD is only one, for which could be used for the resolution of any type of supervised institution member of IGD.
} 
19. INSAFOCOOP should be strengthened to be able to perform certain prudential supervision of cooperatives that are outside the regulatory perimeter of the SSF ${ }^{11}$. It should include not only the allocation of greater resources but also mechanisms to ensure the separation of the functions between promotion and supervision, as well as adequate training of its staff. This monitoring would not only improve the functioning of the cooperatives outside the regulatory perimeter of SSF but also would help them prepare for their inclusion in the SSF's regulatory perimeter.

\section{SELECT LATIN AMERICAN EXPERIENCES ON SUPERVISION OF NBSCI}

20. Some Latin-American countries have adopted -with different approaches- the auxiliary supervision in their supervisory scheme of NBSCI. Some examples are Mexico, Brazil, Ecuador, Colombia and Peru. There are differences in the degree of delegation and the usage of independent third parties, as well as the role of the federation and the involvement of the supervisory agency. This section contains a brief description of the cases of Mexico, Brazil and Ecuador. Although these countries might have a more developed NBSCI sector and its regulatory/supervisory framework, they could provide useful insights for the case of El Salvador.

\section{A. The case of Mexico}

\section{The legal and regulatory framework of the NBSCI sector in Mexico has been} undergoing substantial changes in the past 7 years. The Popular Savings and Credit Law dates from 2001. During 2009 a new legal framework was approved for the sector, establishing a specific law for the regulation of the saving and loan cooperatives (SCAP). Another legal framework was introduced for the regulation of the "for-profit" financial institutions such as Sociedades Financieras Populares, (SOFIPO, Popular Financial Companies). Other actors in the sector include non-deposit taking institutions such as Credit Unions with their own dedicated law and the Sociedades Financieras de Objeto Múltiple (SOFOM, Multi-Purpose Financial Companies), which are covered by the General Law of Auxiliary Credit Organizations and Activities ${ }^{12}$. Figure 3 describes the type and number of NBSCI, whether they are deposit taking institutions and prudentially regulated by the banking supervision agency (Comisión Nacional Bancaria y de Valores - CNBV), who performs the different type of supervision, and if auxiliary supervision is used in prudential regulation.

\footnotetext{
11 The new draft law contemplates the requirement to non-regulated coops to submit quarterly financial statements to the SSF. Additionally, they would be obliged to send monthly information on their credit portfolio, deposits and other obligations.

12 This law covers also leasing and factoring companies, which are outside the scope of this Technical Note.
} 


\section{Figure 3: NBSCI in Mexico *}

\begin{tabular}{|c|c|c|c|c|c|c|}
\hline \multirow{2}{*}{$\begin{array}{l}\text { As of September } 2015 \text { except } \\
\text { unregulated SOFOMs (as of } \\
\text { January 2016) }\end{array}$} & \multirow{2}{*}{$\begin{array}{l}\text { Number } \\
\text { of insti- } \\
\text { tutions }\end{array}$} & \multirow{2}{*}{$\begin{array}{c}\text { Deposit } \\
\text { taking }\end{array}$} & \multicolumn{4}{|c|}{ Supervision } \\
\hline & & & $\begin{array}{l}\text { Market } \\
\text { Conduct }\end{array}$ & $\begin{array}{c}\text { Auxiliary } \\
\text { Supervision }\end{array}$ & Prudential & AML \\
\hline SOFIPO & 44 & Yes & Condusef & Yes & CNBV & CNBV \\
\hline SOFOM regulated** & 31 & No & Condusef & No & CNBV & CNBV \\
\hline SOFOM not regulated & 1,432 & No & Condusef & No & No & CNBV \\
\hline Credit Unions & 98 & No & Condusef & No & CNBV & CNBV \\
\hline \multirow{2}{*}{$\begin{array}{l}\text { SCAP (cooperatives) } \\
\text { SCAP (cooperatives) not } \\
\text { regulated*** }\end{array}$} & 147 & Yes & Condusef & Yes & CNBV & CNBV \\
\hline & 433 & Yes & Condusef & Yes & No & CNBV \\
\hline \multirow{2}{*}{$\begin{array}{l}\text { SOFINCO regulated } \\
\text { SOFINCO not regulated } * * *\end{array}$} & 1 & Yes & Condusef & Yes & CNBV & CNBV \\
\hline & 26 & Yes & Condusef & Yes & No & CNBV \\
\hline \multirow{3}{*}{$\begin{array}{l}\text { Total (regulated institutions) } \\
\text { Total (unregulated institutions) } \\
\text { TOTAL NBSCI }\end{array}$} & 323 & & & & & \\
\hline & 1,891 & & & & & \\
\hline & 2,214 & & & & & \\
\hline
\end{tabular}

* Does not include auxiliary credit institutions (leasing, factoring, and deposit warehouse companies).

** Only when there is an ownership link with banks or they have issue commercial papers in the stock market.

*** Assets below 2.5 million UDIS, or in the process to be authorized by CNBV or under liquidation.

Source: CNBV, Focoop, CONDUSEF, Fedrural.

\section{The CNBV has been incorporating many SCAP under its regulatory and}

supervisory perimeter. The Law for the Regulation of the Activities of the Savings and Loans Cooperatives (LRASCAP) approved in 2009 established a deadline for the SCAP above a certain level of assets (2.5 million UDIs, $\sim \$ 0.75$ million) to become regulated and supervised by CNBV. After several postponements, in April 2014 it was established that the SCAP with assets above 2.5 million UDIs that have not submitted the corresponding authorization request to CNBV would be able to continue receiving deposits and granting credits (only from the current members) subject to a series of requirements related to their willingness to be subject to a consolidation process (e.g. being assessed to determine if viable or not, presenting balance sheet according to CNBV regulations). Since 2010, 100 new SOCAP were authorized (Figure 4), most of them during 2013.

Figure 4: New licenses for NBFIs in Mexico

\begin{tabular}{ccccc}
\hline & SCAP & SOFIPO & SOFINCO & $\begin{array}{c}\text { Credit } \\
\text { Union }\end{array}$ \\
\hline 2010 & 9 & 3 & - & - \\
2011 & 5 & 3 & - & - \\
2012 & 7 & - & - & - \\
2013 & 62 & 3 & 1 & - \\
2014 & 12 & 3 & - & - \\
2015 & 5 & - & - & - \\
\hline
\end{tabular}

Source: Annual Reports of CNBV.

23. The legal framework establishes auxiliary supervision -through the Federations- for both SOFIPO and SCAP, as well as certain roles to them on resolution and deposit insurance. Each Federation has a specific auxiliary supervisory committee (whose members are appointed by the Technical Committee formed by representatives of the affiliated institutions) and exercise direct supervision of the institutions assigned. They must perform an assessment of any institution that 
wishes to get a license from CNBV. Its supervisory process and manuals have to be approved by CNBV, and they must regularly send reports to CNBV. The deposit insurance scheme is separated from the bank's deposit insurance fund, and is administrated by a specific Committee made up of representatives of the sector; with deposit insurance coverage is around $\$ 7,800$, compared with the \$125,000 established for bank's deposits.

24. The experience of auxiliary supervision of the SOFIPO has shown weaknesses. Each SOFIPO can choose a Federation (there are 6) to be affiliated and to be (auxiliary) supervised, with the possibility of moving to another Federation. The SOFIPO's power to choose and to change their supervising federation creates a conflict of interest for the federations, because thorough supervision may lead their members to shift to other federations. The conflict of interest is particularly strong, when the SOFIPO is large relative to the federation. Additionally, the lack of standardization in the auxiliary supervision methodology (each federation has its own "technology") and the deficient validation of the SOFIPO's information turned the auxiliary supervision for the CNBV into more of a burden than a help. In practice, CNBV is currently performing supervision as if there were no auxiliary supervision, which is inefficient and costly for the sector. In this context, taking into account the negative experiences of auxiliary supervision with the SOFIPOs' Federations, and the reduced (compared with SCAP) number and limited geographical dispersion of the SOFIPO, the supervisors are considering legal amendments to enable direct supervision.

\section{The auxiliary supervision of SCAP sector is performing relatively well; the} significant number of SCAP included in the regulatory perimeter poses challenges for CNBV. In the case of the cooperative sector, there is only one supervisory committee which facilitates CNBV the process of revision of their supervisory manuals and policies, as well as the quality of the information on cooperatives provided to CNBV. The Supervisory Committee has a good reputation in the market and plays an important role not only for supervising the institutions that are within the regulatory perimeter but also to collect information from the smallest one (below 2.5 million UDIs, $\sim \$ 0.75$ million of assets). The incorporation in the regulatory perimeter of 100 SOCAP in the last 5 years demands supervisory efforts from the $\mathrm{CNBV}$, including the continuous revision of the appropriateness and effectiveness of the supervisory methodology applied by the auxiliary supervision.

\section{B. The case of Brazil}

26. Brazil has a significant a number of financial cooperatives, most of them organized in 2-3 levels and with a broad geographical distribution. As of mid-2015 there were 1,100 cooperatives, 35 Central Cooperatives (CC), operating at the second level, and 2 confederations at the third and highest level. The cooperatives have presence in almost all states of the country, with no systemic impact (2.2\% of share in total assets of the financial system).

27. The supervisory scheme of the NBSCI is based on delegated supervision, with a key role set for the Central Cooperatives (CC). The Central Bank of Brazil (CBB), through the specific department in charge of the supervision of the NBSCI, has direct supervisory powers for the CC and for the individual independent cooperatives; while the CC are the main supervisory body of the individual cooperatives (see Figure 5). The CC has the responsibility of supervising the affiliated cooperatives, verifying their compliance with regulation and recommending and imposing corrective actions. Its supervisory activity should be on a continuous basis (both offsite and on-site), in a proportional way (considering the volume and complexity of the cooperatives to be supervised), and with the adequate resources. The CBB's regulation has set 
what should be covered by the evaluation process of the CC to the individual cooperative, establishing it has to include an assessment on the adequacy of: institutional policies, governance practices, risk management, internal control systems and compliance with applicable laws and regulations. Additionally, the CBB has established guidelines in terms of the activity that should be performed during on-site and off-site supervision

Figure 5: Structure of the supervision of financial cooperatives in Brazil

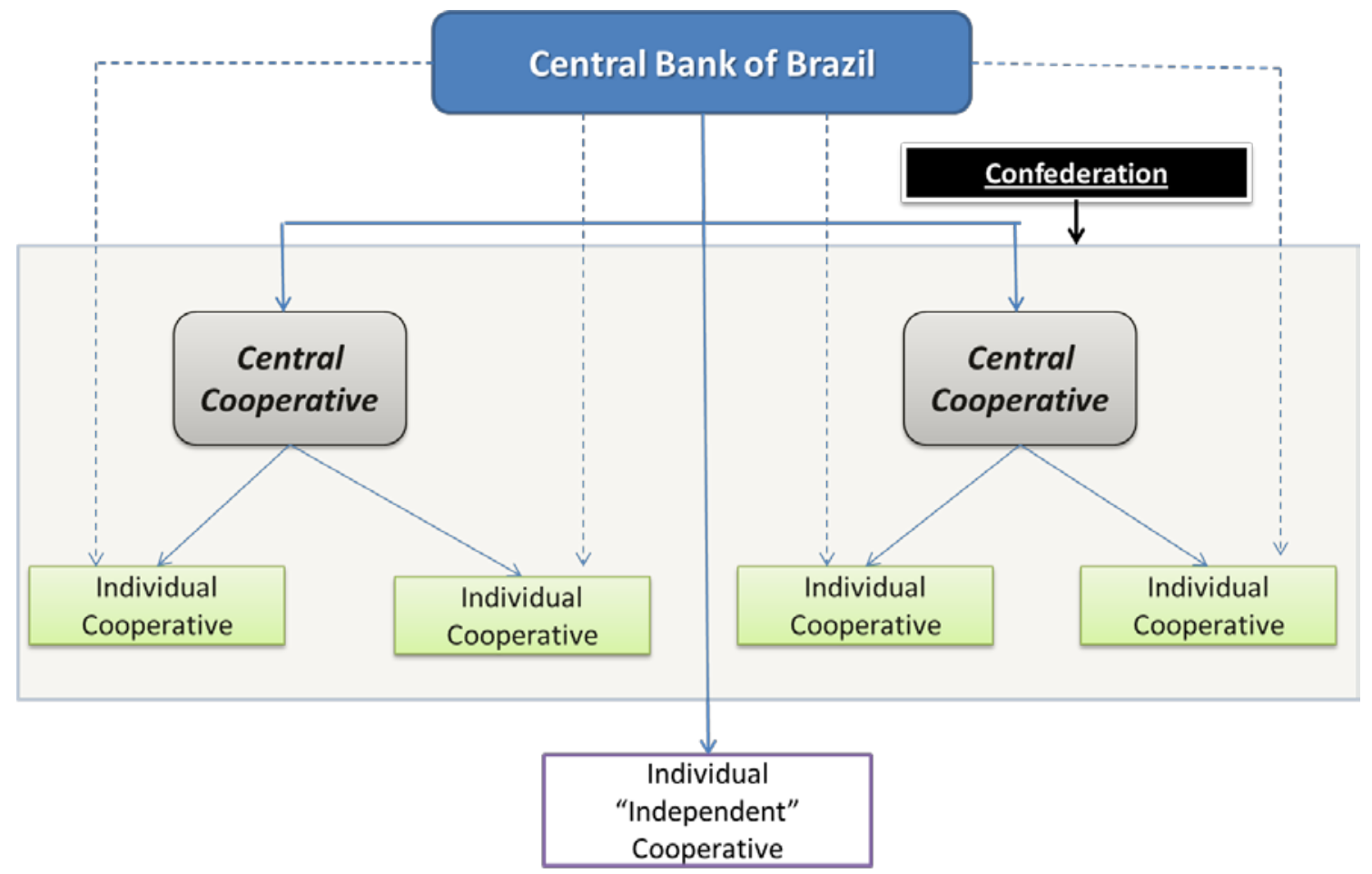

Note: full arrow implies direct supervision, while dotted arrows are indirect Source: FSAP analysis based on Central Bank of Brazil (CBB) information

28. The CC have to submit information to CBB regarding the past and future direct supervision plan, as well as on any relevant fact detected in an individual cooperative during the supervisory process. Before the end of each September, the CC has to submit to the CBB the annual program projected for on-site supervision of the individual cooperatives for the following year; and by the end of March of each year the results of the supervisory program of the previous year. In addition, the CC has to send to the CBB -within the following 30 days of identification- any relevant facts detected during the on-site and/or off-site supervision of cooperatives, as well as the actions to be implemented to address them.

29. The CBB has the power to affect the supervisory program of the $\mathrm{CC}$, as well as to ask for specific tasks and information. Ad-hoc requirements from CBB to CC could cover: (a) adjustments to the annual supervisory program including changes in the frequency, scopes and prioritization of the on-site supervision to be performed by the CC, (b) requirements for tasks to be done and information to be provided with specific deadlines (that could differ from the regular ones already included in the regulation).

30. The Cooperatives have their own Deposit Insurance System. The "Fundo Garantidor do Cooperativismo de Crédito (FGCoop)" was created in 2012, and it covers deposits and other credits held at the singular cooperative or a cooperative bank in case of intervention or extrajudicial liquidation. Currently, the coverage of the deposits insurance for cooperatives is the same amount that the established for banks. 


\section{The case of Ecuador}

31. The cooperative sector of Ecuador comprises a significant number of institutions, with 946 saving and loan cooperatives supervised by the Superintendency of Popular and Solidarity Economy (SEPS) -see Figure 6.

Figure 6: Organizations of the Popular and Solidarity Economy in Ecuador

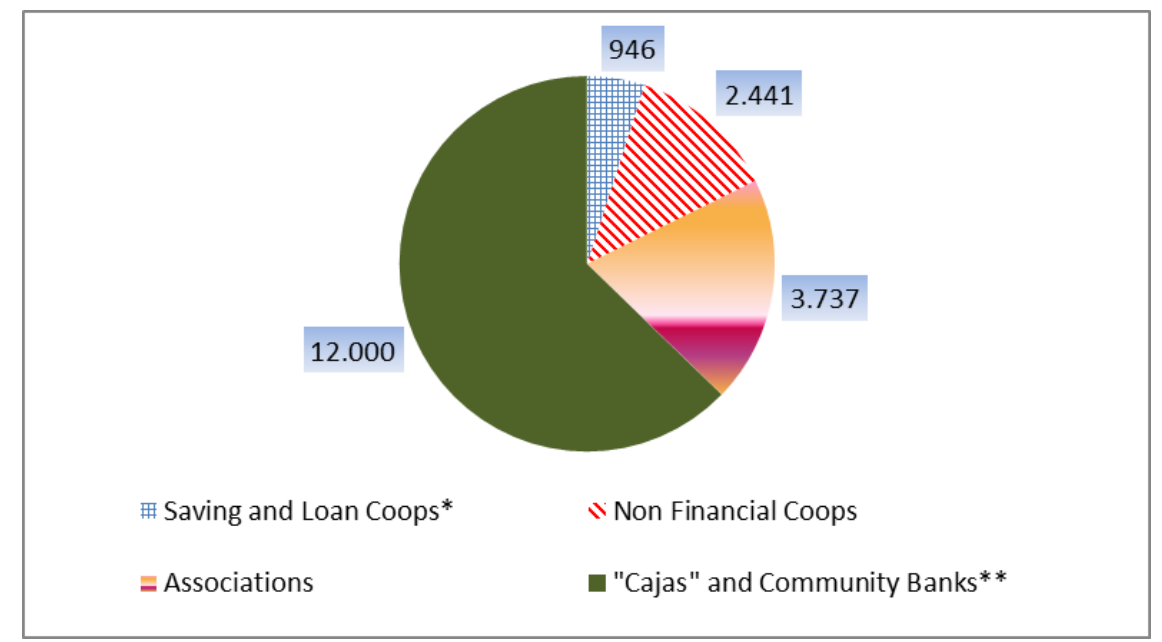

Source: own elaboration based on SEPS

32. The supervision of the NBSCI is performed by SEPS through specialized rating agencies. These agencies have to be registered and rated by SEPS, and their analysts must be certified. They perform off-site and on-site supervision of regulated financial cooperatives and microfinance institutions, using a standardized methodology which includes the type and frequency (quarterly and every half year) of the reports to be provided to SEPS. 
Comparative table on draft laws for expanding the regulatory perimeter ${ }^{13}$

\begin{tabular}{|c|c|c|c|}
\hline Issue/Topic & Version SSF* & Version BCR* & Comments \\
\hline $\begin{array}{l}\text { Requirement to } \\
\text { get basic } \\
\text { information from } \\
\text { institutions } \\
\text { outside the } \\
\text { regulatory } \\
\text { perimeter }\end{array}$ & Not mentioned & $\begin{array}{l}\text { Explicitly established. } \\
\text { They have to provide } \\
\text { quarterly information to } \\
\text { the SSF (June and } \\
\text { December must be } \\
\text { audited.) }\end{array}$ & $\begin{array}{l}\text { There is a need to have } \\
\text { this info available for } \\
\text { SSF and BCR. The } \\
\text { approach to acquire it } \\
\text { should take into account } \\
\text { the sensitivity of the } \\
\text { unregulated sector. }\end{array}$ \\
\hline $\begin{array}{l}\text { Reference to } \\
\text { articles of the } \\
\text { Cooperative } \\
\text { Banking Law } \\
(C B L)\end{array}$ & Intensively used & $\begin{array}{l}\text { Minimized. The text is } \\
\text { "self-contained" } \\
\text { copying a significant } \\
\text { part of the Cooperative } \\
\text { Banking Law (CBL) }\end{array}$ & $\begin{array}{l}\text { The references to the } \\
\text { CBL (instead of } \\
\text { duplicating the text from } \\
\text { it) has the purpose to } \\
\text { assure that any future } \\
\text { changes in the CBL law } \\
\text { automatically applies to } \\
\text { this law. }\end{array}$ \\
\hline $\begin{array}{l}\text { Possibility of } \\
\text { Auxiliary } \\
\text { Supervision }\end{array}$ & $\begin{array}{l}\text { Explicitly include } \\
\text { it, detailing the } \\
\text { tasks, activities and } \\
\text { responsibilities of } \\
\text { the SSF, } \\
\text { Federations and } \\
\text { other specific } \\
\text { "delegated" } \\
\text { auditors (that have } \\
\text { to be registered at } \\
\text { SSF) }\end{array}$ & $\begin{array}{l}\text { Include } 3 \text { general } \\
\text { articles establishing that } \\
\text { the SSF is responsible } \\
\text { for supervision, and } \\
\text { could use the } \\
\text { federations and other } \\
\text { organisms for auxiliary } \\
\text { supervision. }\end{array}$ & $\begin{array}{l}\text { It should be clear that the } \\
\text { SSF keeps the } \\
\text { responsibility for the } \\
\text { supervision of the new } \\
\text { institutions. If auxiliary } \\
\text { supervision is used, it } \\
\text { must be clearly defined } \\
\text { its powers, activities they } \\
\text { have/can perform and } \\
\text { responsibilities. }\end{array}$ \\
\hline $\begin{array}{l}\text { Compensation } \\
\text { for the cost of } \\
\text { the supervision } \\
\text { (included the } \\
\text { auxiliary } \\
\text { supervision) }\end{array}$ & $\begin{array}{l}\text { Established as a } \\
\text { maximum of } \\
0.05 \% \text { of total } \\
\text { asset, to be } \\
\text { distributed } 60 \% \text { to } \\
\text { SSF and } 40 \% \text { to the } \\
\text { Federation. For } \\
\text { entities not } \\
\text { federated, } 100 \% \text { is } \\
\text { assigned to SSF }\end{array}$ & Not considered & $\begin{array}{l}\text { The mechanism for } \\
\text { compensating the cost of } \\
\text { the auxiliary supervision } \\
\text { should be included in the } \\
\text { legal framework }\end{array}$ \\
\hline
\end{tabular}

* Draft laws were provided during the mission

\footnotetext{
${ }^{13}$ At the time this document has been revised, the BCR and SSF has reached an agreement on one consensual draft law.
} 
Comparative table on draft laws for expanding the regulatory perimeter (Cont' $\mathbf{d}$.)

\begin{tabular}{|l|l|l|l|}
\hline Issue/Topic & \multicolumn{1}{|c|}{ Version SSF* } & \multicolumn{1}{|c|}{ Version BCR* } \\
\hline $\begin{array}{l}\text { Insurance } \\
\text { Coverage }\end{array}$ & $\begin{array}{l}\text { The institutions } \\
\text { will be covered by } \\
\text { the Deposits } \\
\text { Insurance Agency } \\
\text { (IGD) once they } \\
\text { have complied with } \\
\text { the initial } \\
\text { regularization plan }\end{array}$ & $\begin{array}{l}\text { Does not include a } \\
\text { deposits insurance } \\
\text { coverage. }\end{array}$ & $\begin{array}{l}\text { Since the regulation will } \\
\text { be very similar to the } \\
\text { cooperative banks, it } \\
\text { should be considered the } \\
\text { provision of deposit } \\
\text { insurance coverage. } \\
\text { Some current weaknesses } \\
\text { on the deposit insurance } \\
\text { scheme should also be } \\
\text { addressed. }\end{array}$ \\
\hline Resolution & $\begin{array}{l}\text { Refers to Chapter } \\
\text { IV and VI of the } \\
\text { Banking Law } \\
\text { (similar to the } \\
\text { treatment at the } \\
\text { CBL) }\end{array}$ & $\begin{array}{l}\text { Includes the } \\
\text { Stabilization Fund (with } \\
\text { some articles that had } \\
\text { been deleted from the } \\
\text { CBL); no reference to } \\
\text { Chapters IV and VI of } \\
\text { the Banking Law }\end{array}$ & $\begin{array}{l}\text { It is very important to be } \\
\text { clear about the process of } \\
\text { resolution (this } \\
\text { uncertainty also exists in } \\
\text { the Cooperative Banks' } \\
\text { Law. }\end{array}$ \\
\hline
\end{tabular}

* Draft laws were provided during the mission 